\title{
Front Matter: Volume 11223
}

, "Front Matter: Volume 11223," Proc. SPIE 11223, Photonic Diagnosis, Monitoring, Prevention, and Treatment of Infections and Inflammatory Diseases 2020, 1122301 (6 March 2020); doi: 10.1117/12.2569642

SPIE. Event: SPIE BiOS, 2020, San Francisco, California, United States 


\title{
Photonic Diagnosis, Monitoring, Prevention, and Treatment of Infections and Inflammatory Diseases 2020
}

\author{
Tianhong Dai \\ Jürgen Popp \\ Mei X. Wu \\ Editors
}

3-4 February 2020

San Francisco, California, United States

Sponsored and Published by

SPIE

Volume 11223 
The papers in this volume were part of the technical conference cited on the cover and title page. Papers were selected and subject to review by the editors and conference program committee. Some conference presentations may not be available for publication. Additional papers and presentation recordings may be available online in the SPIE Digital Library at SPIEDigitalLibrary.org.

The papers reflect the work and thoughts of the authors and are published herein as submitted. The publisher is not responsible for the validity of the information or for any outcomes resulting from reliance thereon.

Please use the following format to cite material from these proceedings:

Author(s), "Title of Paper," in Photonic Diagnosis, Monitoring, Prevention, and Treatment of Infections and Inflammatory Diseases 2020, edited by Tianhong Dai, Jürgen Popp, Mei X. Wu, Proceedings of SPIE Vol. 11223 (SPIE, Bellingham, WA, 2020) Seven-digit Article CID Number.

ISSN: 1605-7422

ISSN: $2410-9045$ (electronic)

ISBN: 9781510632097

ISBN: 9781510632103 (electronic)

Published by

SPIE

P.O. Box 10, Bellingham, Washington 98227-0010 USA

Telephone +1 3606763290 (Pacific Time) · Fax +1 3606471445

SPIE.org

Copyright @ 2020, Society of Photo-Optical Instrumentation Engineers.

Copying of material in this book for internal or personal use, or for the internal or personal use of specific clients, beyond the fair use provisions granted by the U.S. Copyright Law is authorized by SPIE subject to payment of copying fees. The Transactional Reporting Service base fee for this volume is $\$ 21.00$ per article (or portion thereof), which should be paid directly to the Copyright Clearance Center (CCC), 222 Rosewood Drive, Danvers, MA 01923. Payment may also be made electronically through CCC Online at copyright.com. Other copying for republication, resale, advertising or promotion, or any form of systematic or multiple reproduction of any material in this book is prohibited except with permission in writing from the publisher. The CCC fee code is $1605-$ $7422 / 20 / \$ 21.00$.

Printed in the United States of America by Curran Associates, Inc., under license from SPIE.

Publication of record for individual papers is online in the SPIE Digital Library.

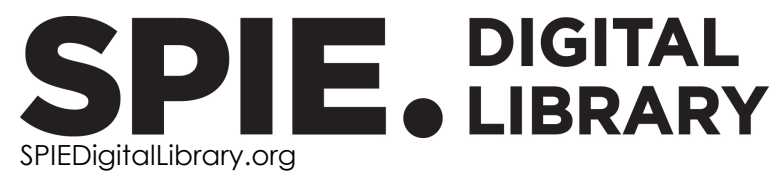

Paper Numbering: Proceedings of SPIE follow an e-First publication model. A unique citation identifier (CID) number is assigned to each article at the time of publication. Utilization of CIDs allows articles to be fully citable as soon as they are published online, and connects the same identifier to all online and print versions of the publication. SPIE uses a seven-digit CID article numbering system structured as follows:

- The first five digits correspond to the SPIE volume number.

- The last two digits indicate publication order within the volume using a Base 36 numbering system employing both numerals and letters. These two-number sets start with 00, 01, 02, 03, 04, 05, 06, 07, 08, 09, OA, OB ... 0Z, followed by 10-1Z, 20-2Z, etc. The CID Number appears on each page of the manuscript. 


\title{
Contents
}

\author{
$\checkmark \quad$ Authors \\ vii Conference Committee
}

\section{SESSION $1 \quad$ PHOTONIC DIAGNOSIS I}

1122302 Deuterium uptake in combination with Raman spectroscopy as a tool to investigate antibiotic susceptibility of bacteria (Invited Paper) [11223-1]

\section{SESSION 2 PHOTONIC DIAGNOSIS II}

1122308 Non-contact Raman spectroscopic pH measurement of cerebrospinal fluid: in vivo rat and perimortem swine models (Invited Paper) [1 1223-7]

1122309 The PVOH device: our first stop on the path to small and very small physical embodiments of the PV[O]H algorithm [1 1223-8]

\section{SESSION $4 \quad$ ANTIMICROBIAL PHOTODYNAMIC THERAPY}

11223 OK Photodynamic therapy: alternative in decontamination of surfaces [11223-20]

SESSION 6 LIGHT-ASSISTED DELIVERY OF ANTIMICROBIALS

$112230 Q \quad$ Improving antibiotics' penetration and efficiency for treating biofilm infections by laserinduced vapor nanobubbles (Invited Paper) [11223-26]

11223 OR Photo-released drugs: a targeted treatment approach for arthritis (Invited Paper) [11223-27]

11223 OS New materials for laser welding of connective tissue and controlled release of antimicrobial principles [1 1223-28]

\section{SESSION 7 NEW MECHANISMS AND MISCELLANEOUS}

11223 OT Inhibiting staphylococcus aureus antibiotic resistance via photo-disassembly of membrane microdomains (Invited Paper) [1 1223-29] 
$112230 \mathrm{~V}$ Investigation of active matrix-metaloproteinase-8 (aMMP-8) as a reference parameter for path control in antimicrobial photothermal therapy (aPTT) using a split-mouth design (Invited Paper) [11223-31]

\section{POSTER SESSION}

1122315 Optical properties of human gums after photodynamic therapy with methylene blue (in vitro) [11223-43] 


\section{Authors}

Numbers in the index correspond to the last two digits of the seven-digit citation identifier (CID) article numbering system used in Proceedings of SPIE. The first five digits reflect the volume number. Base 36 numbering is employed for the last two digits and indicates the order of articles within the volume. Numbers start with 00, 01, 02, 03, 04, 05, 06, 07, 08, 09, OA, OB...0Z, followed by 10-1Z, 20-2Z, etc.

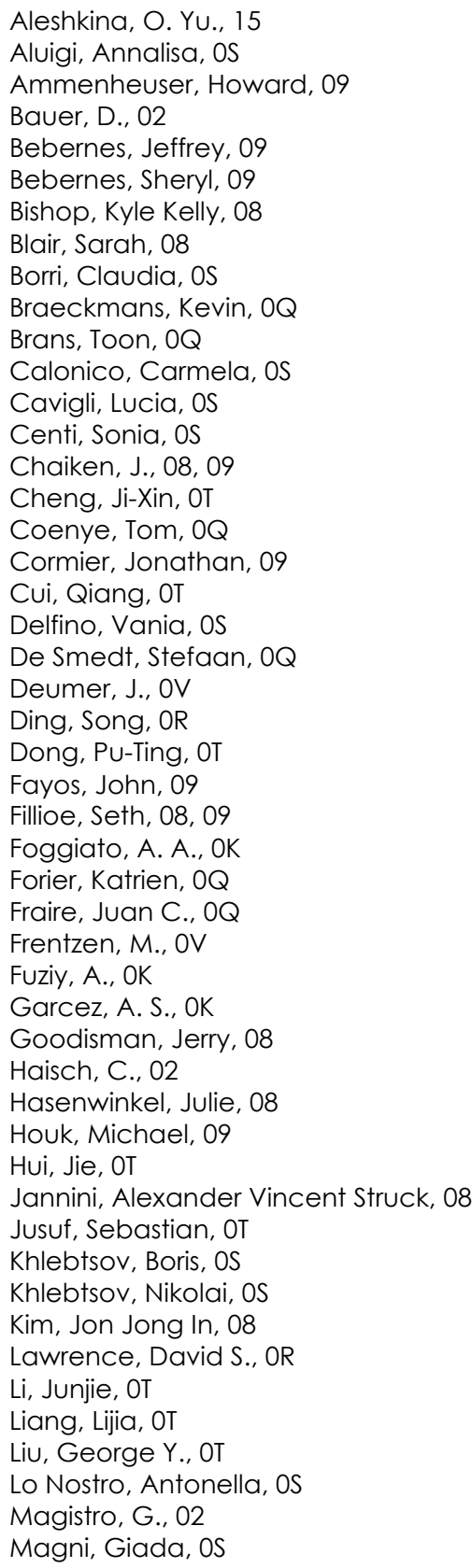

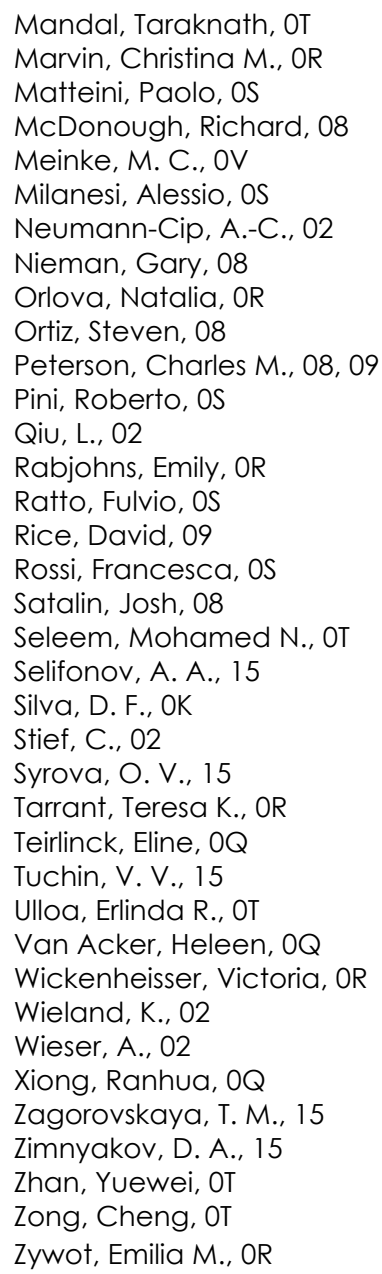


Proc. of SPIE Vol. 11223 1122301-6 Downloaded From: https://www.spiedigitallibrary.org/conference-proceedings-of-spie on 25 Apr 2023
Terms of Use: https://www.spiedigitallibrary.org/terms-of-use 


\title{
Conference Committee
}

\author{
Symposium Chairs
}

Jennifer K. Barton, The University of Arizona (United States)

Wolfgang Drexler, Medizinische Universität Wien (Austria)

Program Track Chairs

Brian Jet-Fei Wang, Beckman Laser Institute and Medical Clinic,

University of California, Irvine (United States)

Eva Sevick, The University of Texas Health Science Center at Houston

(United States)

\section{Conference Chairs}

Tianhong Dai, Wellman Center for Photomedicine (United States) and Massachusetts General Hospital (United States) and Harvard Medical School (United States)

Jürgen Popp, Leibniz-Institut für Photonische Technologien e.V. (Germany)

Mei X. Wu, Harvard Medical School (United States)

Conference Program Committee
Alessandro M. Deana, UNINOVE (Brazil)
Pu-Ting Dong, Boston University (United States)
Walfre Franco, Wellman Center for Photomedicine (United States)
Michael R. Hamblin, Wellman Center for Photomedicine (United States)
Kristen C. Maitland, Texas A\&M University (United States)
Akilan Palanisami, Wellman Center for Photomedicine (United States) and Massachusetts General Hospital (United States) and Harvard Medical School (United States)
Wei-Chuan Shih, University of Houston (United States)
Ying Wang, Chinese PLA General Hospital (China)

Session Chairs

1 Photonic Diagnosis I

Mei X. Wu, Harvard Medical School (United States)

2 Photonic Diagnosis II

Christoph Haisch, Technische Universität München (Germany) 
3 Photonic Diagnosis III

Francesco Baldini, Istituto di Fisica Applicata "Nello Carrara" (Italy)

4 Antimicrobial Photodynamic Therapy

Kristen C. Maitland, Texas A\&M University (United States)

5 Antimicrobial Blue Light

Pu-Ting Dong, Boston University (United States)

$6 \quad$ Light-Assisted Delivery of Antimicrobials

Walfre Franco, Wellman Center for Photomedicine (United States)

7 New Mechanisms and Miscellaneous

Tianhong Dai, Harvard Medical School (United States) 